\author{
MILENA M. VUJIČIĆ ${ }^{1}$ \\ UNIVERSITY OF Niš, FACULTY OF PHILOSOPHY, \\ PSYCHOLOGICAL COUNSELING FOR STUDENTS, SKC NIŠ \\ DUŠAN J. RANĐELOVIĆ \\ UNIVERSITY OF PRIŠTINA WITH TEMPORARY HEAD OFFICE \\ IN Kosovska Mitrovica, Faculty of Philosophy \\ DEPARTMENT OF PSYCHOLOGY
}

\title{
PERSONALITY TRAITS AS PREDICTORS OF DEPRESSION, ANXIETY, AND STRESS WITH SECONDARY SCHOOL STUDENTS OF FINAL YEARS ${ }^{2}$
}

ABSTRACT. The main aim of this research is to examine the predictive power of personality traits, as defined by the Big five model of personality in expressing depression, anxiety, and stress with secondary school students of final years. The research was conducted on a sample of 977 secondary school students in the third and fourth grade from ten secondary schools in Niš. The gender structure of the sample was as follows: 397 boys and 607 girls. The following instruments were used in the research: Depression Anxiety Stress Scales (DASS-21; Lovibond and Lovibond, 1995), Big Five Inventory BFI (John, Donahue and Kentle, 1991). The results showed that the regression model constructed by personal traits (Extraversion, Agreeableness, Conscientiousness, Neuroticism, and Openness to experience) explain $26 \%$ of the criterion variable of Anxiety. The largest individual contribution to

\footnotetext{
milenamvujicic@gmail.com; alkadule9@yahoo.com

2 This study was conducted in the framework of the project Kosovo and Metohija between national identity and Euro-Integrations which was financed by the Ministry of Education, Science, and Technological Development (project number III 47027).

This paper was submitted on August 5, 2017 and accepted for publication at the meeting of the Editorial Board held on September 19, 2017.
} 
the prediction of this variable is achieved by the personal trait Neuroticism $(\beta=.34, p<0.01)$. Other personal traits that contribute to the prediction of this variable at a statistically significant level are Extraversion $(\beta=-.17$, $p<0.01)$, Agreeableness $(\beta=-.14, \quad p<0.01)$ and Conscientiousness $(\beta=-.17$, $\mathrm{p}<0.01)$. The same model explains $37 \%$ of the criterion variable Stress. The largest individual contribution to Stress prediction is achieved by the personal trait Neuroticism $(\beta=.57, p<0.01)$. The same model explains $27 \%$ of the criterion variable Anxiety as well. The largest individual contribution to the prediction of this variable is achieved by the personal trait Neuroticism $(\beta=.45, p<0.01)$, whereas a statistically significant correlation between personal traits Agreeableness $(\beta=-.06, p<0.05)$ and Conscientious $(\beta=-.12$, $\mathrm{p}<0.01)$ exists. Results show that the difference between boys and girls in expressing Anxiety $(\mathrm{t}=-2.96, \mathrm{p}<0.01)$ and Stress $(\mathrm{t}=-5.01, \mathrm{p}<0.01)$ exists. These emotional states are more expressive with girls. However, there are no differences in expressing Depression, Anxiety, and Stress with secondary school students of the third and fourth grade on the examined sample.

KEY WORDS: personality traits, depression, anxiety, stress, secondary school students.

\section{INTRODUCTION}

Final years of secondary school represent a period of making significant life decisions regarding further professional training or vocation choice. Besides studying the current school material, students face the decision of future life vocation (in both, academic and professional sense). The right choice of vocation represents one of the most significant tasks for a young person which will direct the entire personal and professional development. A number of young people find themselves at a crossroads; they are often insecure about the choice of the faculty; they feel insecure about their own capacities and powers and they are insufficiently informed about the job market and the principles of its functioning, so they choose to continue their parents' jobs, or they choose their jobs according to their friends' choices. Having in mind that this is still an adolescent population, the number of challenges for them to face is even bigger. What is characteristic for this period of adolescence is increased emotionality and general emotional sensitivity which peak in adolescence. Adolescence is described as a period of vast possibilities for growth and development, but also a period of conflicts of extremes in mood, emotions, energy, ideology; a period full of conflicts (Wenar, 2003). All of the above 
mentioned could contribute to a larger degree of anxiety and a smaller degree of stress and depression tolerance with a young person not ready for an array of changes he/she is expected to experience. A number of factors influences whether and in which ways these states will manifest, but what is expected is that personal traits of a young person have a part in their expression. Individual differences will influence certain persons to be more vulnerable to stress experiences, whereas other individuals perceive the same stressor with lower intensity.

This research will pay particular attention to the role of personal traits in stress, anxiety, and depression prediction based on a sample of secondary school students in Niš. The students who participated in the survey were of the third and fourth grade, and they are expected to express particular sensitivity to changes and certain emotional states as an inappropriate response to them. In addition to that, existence of differences between genders, as well as between the students of the third and fourth grade in expressing depression, anxiety, and stress will be examined.

\section{PERSONALITY TRAITS}

Striving to describe a person we most often list characteristics we believe they possess. There are a lot of terms we use in order to describe the world around us. Within psychology of personality, a number of authors examined the structure of personality, as well as the significance of personality characteristics for a better understanding of human behavior. A personality is defined in different ways; however, what is a common characteristic of numerous definitions is implied existence of certain permanent or relatively permanent personal traits which determine characteristic and consistent behavior of a person.

A comprehensive understanding of a personality as a whole requires a detailed examination of an array of personality system elements (lines, aims, skills, etc.) in order to examine their specific, but also common contribution to forming ways in which people shape their lives (Bleidorn et. al., 2010, according to Otašević and Kodžopeljić, 2016).

One of the most widely accepted theoretical personality models is the five-factor model, the structure of which stems from theories of personality and a lexical hypothesis which implies that diction- 
aries of everyday language adequately express individual differences related to social and psychological reality. It is based on the assumption that all the important descriptions of a personality exist in natural language. Therefore, by providing an adequate sample of terms, one can obtain a group of personality traits which is both comprehensive and valid, and based on which people can describe themselves. Factorization of such a group of variables produces latent dimensions which lie in the basis of individual differences regarding the lines of personality (Međedović, 2009). The author of the "Big Five" model, Goldberg (1990), believed that the number of five factors is optimal for an adequate description of the personality space. These factors are as follows: Neuroticism, Extraversion, Openness to experience, Agreeableness, and Conscientiousness. A similar model, although based on the self-evaluation of a questionnaire type was developed by McCrae and Costa (1990, according to Marić, 2010). Extraversion and Neuroticism represent the basic axes of the five-factor model, and some researchers suggest renaming these constructs into "positive" and "negative" emotionality, having in mind a high level of correlation between Extraversion and positive and Neuroticism and negative emotional states (Tellegen, 1982, according to Krapić, 2005). The explanation for such a suggestion is represented in the fact that both lines are consequences of the same behavioral systems which exist in the basis of emotional states (Davidson, 2001; Gray, 1990; according to Krapić, 2005), assuming that Extraversion is the consequence of behaviorally activating system, whereas Neuroticism is a consequence of behaviorally inhibiting one. Each dimension of the five-factor model consists of several low order components, i.e. facets which represent basic characteristics of an individual (John and Srivastava, 1999). Extraversion, characterized by positive emotionality, includes sociability, enterprise, ambition, and assertiveness as its components, whereas Neuroticism, or negative emotionality, consists of emotional reactivity, irritability, and insecurity. Within Agreeableness, among low order facets, there are kindness, cooperativeness, and tendency toward helping, whereas Conscientiousness includes components, such as urge to control (as opposed to being impulsive), caution, reliability, responsibility, tendency toward hard work and achievements. Openness to experience includes intellect in its narrow sense (intelligence, cleverness, creativity), openness to experience (curiosity, imagination, liberality), as well as certain aspects of culture, personal attitudes, 
tendencies, and orientations such as interest in art, non-conformity, progressive and unconventional values, and urge for different experiences (McCrae and Costa, 1991).

\section{DEPRESSION, ANXIETY AND STRESS}

Depression, anxiety, and stress represent negative affective states and their absence implies mental health and psychological well-being (Diener et al., 2010). Depression is defined as an emotional state characterized by sadness, the sense of worthlessness and guilt, insomnia, the loss of appetite and sexual desire, pulling in, the loss of interest in usual activities, as well as the lack of satisfaction related to these activities. One of the main characteristics is also rumination, which could interfere with adequate problem solving and lead to problems in family relations or relationships with friends, which could then lead to increasing seriousness of depressive mood developing into a great depressive disorder (Nolen-Hoeksema, 2000).

Depression symptoms are noted by a majority of people throughout their life. However, not all of them reach the quality of pathological depression. Besides depression symptoms, within normal developmental changes, anxiety symptoms may occur. Anxiety is most often assessed on the basis of three different levels: behavioral, subjective, and physiological. Psychic manifestations of anxiety are an unpleasant state of fear, concern, worry, tension, nervousness, and irritability. Symptoms such as psychomotor unrest, accelerated heartbeat and breathing, the felling of having short breath, muscular tension, stomach problems, and excessive sweating occur on the physiological plan (Wenar, 2003). Anxiety could be viewed as both a state and a line of personality. Anxiety as a state is related to emotional reactions to internal and external threats perceived by a person, whereas anxiety as a line of personality refers to a general tendency of perceiving threats in a wide range of stimuli (Spielberger, 1972). Stress is usually defined either as an event in the external surrounding including the activation of intense, usually negative feelings and/or a group of characteristic bodily reactions (Zotović, 2002). The way we experience stress will depend on the characteristics of an individual who found themselves in a stressful situation and the characteristics of the situation itself. Individual characteristics determine what is impor- 
tant for the sense of well-being in a particular situation, shaping the individual's understanding of the event itself, which, afterwards, influences the way of coping with the stressful situation. Depending on the circumstances, an individual chooses the ways of facing the stressful situation. The strategies of facing are not assessed as universally good or bad, but through the level of appropriateness for a particular situation (Hudek - Knežević, Krapić and Kalebić-Maglica, 2009).

The occurrence of negative affective responses in the adolescence is influenced by a particular set of factors related to the personalities of adolescents themselves and the characteristics of their immediate and extended surrounding. Numerous studies imply possible factors contributing to the occurrence of negative emotional responses, such as conflicts with their parents, teachers, peers, studying problems, "unfortunate loves" which gain completely new dimension in this particularly sensitive period (Rutter, 1981).

Assessing unpleasant emotions and symptoms of psychological distress is one of the tasks psychologists face on a daily basis, in both, practice and research. Having in mind that the presence of unpleasant emotions is often a companion of a majority of psychic issues, numerous instruments for assessing different unpleasant emotional states have been developed (Werner and Gross, 2004, according to Jovanović, Gavrilov-Jerković, Žuljević and Brdarić, 2014). Depression is assessed as a low level of positive affect, dysphoria, hopelessness, the loss of interest, a negative attitude towards oneself and life in general. Anxiety is described with the aid of the physiological excitement symptoms such as dry mouth, difficulties in breathing, shivering, as well as subjective perception of anxious affect. Stress dimension refers to the symptoms of general, non-specific excitement, such as difficulties in relaxation, irritability, and grumpiness (Jovanović \& al., 2014).

\section{RELEVANT RESEARCH ON PERSONALITY TRAITS AND NEGATIVE EMOTIONAL STATES}

A number of researches has shown that if emotionality on the level of positive and negative affect is generalized as the level of happiness and well-being, these constructs depend on personality traits 
to a great extent (Costa, McCrae and Zonderman, 1987; Diener and Diener, 1996, according to Mroczek and Kolarz, 1998). Personality traits that are, in different researches, consistently emotionally coloured are Neuroticism and Extraversion (Costa and McCrae, 1980; David, Green, Martin and Suls, 1997; Lucas and Fujita, 2000; Meyer and Shack, 1989; Watson and Clark, 1992, according to Marić, 2010). The research on general affective dimensions of personality confirm that negative affectivity as a line of personality correlates with Neuroticism characteristics. Anxiety and hostility, as indicators of Neuroticism, are dispositional forms of two primary negative emotions: fear and anger. As a sub-scale, being discouraged is related to depressive mood, sadness, hopelessness, and guilt (John and Srivastava, 1999). Contrary to that, as a line, positive affectivity is in a strong correlation with Extraversion. Three Extraversion sub-scales referring to temperament are activity, searching for excitement, and positive emotions. An active and exciting life of an extrovert could represent a reflection of striving toward an experience of positive emotions (Smederevac and Mitrović, 2006). Other personality traits of the five-factor model Openness to experience, Agreeableness, and Conscientiousness are usually positively correlated to positive affectivity, while being in a negative correlation with experiencing negative emotions (McCrae and Costa, 1991; Watson and Clark, 1992). Studies mostly show that these characteristics are correlated to emotional states to a significantly lower extent than Extraversion and Neuroticism (McCrae and Costa, 1991). In cases of present correlations, Agreeableness is usually positively correlated with positive affective responses, and negatively with negative emotional reactions (McCrae and Costa, 1991; Watson and Clark, 1992).

\section{METHOD}

RESEARCH

PROBLEM

The main problem of this research is to examine whether personality traits, as defined by the Big five model of personality are statistically significant predictors of depression, anxiety, and stress with secondary school students in higher grades.

THE GENERAL It is expected that statistically significant power of personality RESEARCH traits in expressing depression, anxiety, and stress with secondary HYPOTHESIS school students will be determined. 
RESEARCH

VARIABLES

REGISTERED

SOCIODEMO-

GRAPHIC

VARIABLES

RESEARCH INSTRUMENTS
Personality traits (Extraversion, Neuroticism, Conscientiousness, Openness to experience, and Agreeableness) measured by scores on sub-scales of the Big five Inventory of Personality (Big five Inventory - BFI; John et. al., 1991).

Depression, anxiety and stress - these variables are measured by scores on sub-scales of the Depression Anxiety Stress Scales (DASS-21; Lovibond and Lovibond, 1995).

- Gender (two-level categoric variable: 1 - male; 2 - female)

- School (ten-level categoric variable: 1 - "Svetozar Marković" Gymnasium school; 2 - "Stevan Sremac" Gymnasium school; 3 - "Bora Stanković Gymnasium school; 4 - "9. maj” Gymnasium school; 5 - Economic school, 6 - Tourism school, 7 - Trade school; 8 - Food-chemistry school; 9 - Medical school; 10 - Music school.

- Grade (two-level categoric variable: 1 - the third grade i 2 - the fourth grade)

Big five Inventory (Big five Inventory - BFI; John et. al., 1991). BFI represents measuring of personal traits of the Big five model. The inventory includes 44 claims followed by a five-degree Likert-type scale for answers. The reliability of the inventory sub-scales on the sample of 599 general population members is satisfactory and amounts as follows: .69 for Extraversion, .70 for Agreeableness, .66 for Conscientiousness, .65 for Neuroticism, and .81 for Openness to experience (Otašević \& Kodžopeljić, 2016). On the studied sample including 977 secondary school students, sub-scales Extraversion $(\alpha=.46)$ and Openness to experience $(\alpha=.47)$ do not show satisfactory reliability, whereas the Cronbach's alpha quotient for other sub-scales amounts as follows: .68 for Agreeableness, .68 for Conscientiousness, and .77 for Neuroticism.

Depression Anxiety Stress Scales (DASS-21; Lovibond and Lovibond, 1995). This scale includes three sub-scales with seven claims each: Depression (e.g. "I felt that I didn't have anything to hope for."), Anxiety (e.g. "I felt scared for no reason."), and Stress (e.g. "I noticed that I was nervous"). Examinees answer using a four-degree Likert-type scale (from 0-not at all to 3-always or almost always), assessing the ways they felt during the recent weeks. The research will use the official translation of DASS-21 scale in the Serbian language. The majority of researches in Serbia have shown solid metric characteristic of this instrument on 
adolescent population (Jovanović et al, 2004). The reliability of the entire scale on the examined sample of 977 secondary school students, expressed by the Cronbach's coefficient is high and amounts 0.91 .

SAMPLE The sample included 977 secondary school students of higher grades coming from ten secondary schools in Niš. Schools included in the research were as follows: four Gymnasiums schools (total of 418 students), Economy school (total of 101 students), Tourism school (total of 109 students), Trade school (total of 103 students), Food-chemistry school (total of 100 students), Medical school (total of 100 students) and Music school (total of 46 students). The students were in their third year (473 students) and fourth year (504 students). As far as the gender structure is concerned, there were 369 boys and 607 girls.

\section{RESEARCH RESULTS}

\begin{tabular}{|c|r|r|rr|}
\hline & \multicolumn{1}{|c|}{ MINIMUM } & \multicolumn{1}{|c|}{ MAXIMUM } & AS & \multicolumn{1}{c|}{ SD } \\
\hline STRESS & .00 & 21.00 & 8.70 & 4.60 \\
\hline ANXIETY & .00 & 21.00 & 4.77 & 4.23 \\
\hline DEPRESSION & .00 & 21.00 & 5.04 & 4.50 \\
\hline EXTRAVERSION & 11.00 & 79.00 & 27.56 & 4.75 \\
\hline AGREEABLENESS & 15.00 & 54.00 & 34.49 & 5.39 \\
\hline CONSCIENTIOUSNESS & 14.00 & 43.00 & 30.64 & 5.46 \\
\hline NEUROTICISM & 8.00 & 40.00 & 24.16 & 6.09 \\
\hline OPENNESS TO EXPERIENCE & 19.00 & 47.00 & 35.54 & 4.85 \\
\hline \hline
\end{tabular}

TABLE 1: AN OVERVIEW OF DESCRIPTIVELY STATISTICAL INDICATORS ON THE BASIC RESEARCH VARIABLES (TABELA 1. PRIKAZ DESKRIPTIVNO STATISTIČKIH POKAZATELJA NA OSNOVNIM VARIJABLAMA ISTRAŽIVANJA)

On the Depression Anxiety Stress Scale (DASS-21) the range of scores is from 0 to 21 . The highest average score was reached on the dimension Stress. At the same time, the largest deviation is noted on the same scale. 
On the Big five Inventory (BFI), the range of scores is the highest on the personality dimension Extraversion $(11,79)$, and the lowest on the personality dimension Conscientiousness $(14,43)$. The highest average values students achieved on items referring to the personality trait Openness to experience, whereas the largest deviation of the average value is on the personality trait Neuroticism.

\begin{tabular}{|c|c|c|c|}
\hline & & DEPRESSION & \\
\hline & $\beta$ & Statistical significance & \multirow{6}{*}{$\begin{array}{l}\text { Model summary } \\
\mathrm{R}=.51 \\
\mathrm{R}^{2}=.26 \\
\text { Statistical significance }=.00\end{array}$} \\
\hline EXTRAVERSION & -0.17 & 0.00 & \\
\hline AGREEABLENESS & -0.14 & 0.00 & \\
\hline CONSCIENTIOUSNESS & -0.17 & 0.00 & \\
\hline NEUROTICISM & 0.34 & 0.00 & \\
\hline OPENNESS TO EXPERIENCE & 0.00 & 0.79 & \\
\hline
\end{tabular}

TABLE 2: REgRESSION ANALYSIS: MULTIPLE REgRESSION ANALYSIS (ENTER PROCEDURE): PERSONALITY TRAITS AS DEPRESSION PREDICTORS (TABELA 2. REgRESIONA ANALIZA: MulTiPLA REgRESIONA ANALIZA (ENTER POSTUPAK): OSOBINE LIČNOSTI KAO PREDIKTORI DEPRESIVNOSTI)

The regression model made by personality traits (Extraversion, Agreeableness, Conscientiousness, Neuroticism, and Openness to experience) explains $26 \%$ of criterion variable Anxiety. The largest individual contribution to the prediction of this variable is achieved by the personality trait Neuroticism $(\beta=.34, p<0.01)$. The direction of the regression coefficient implies that based on the increased values on Neuroticism, a higher result on the Depression scale may be expected. The other personality traits which contribute to the prediction of the criterion variable in a statistically significant way are Extraversion $(\beta=-.17, p<0.01)$, Agreeableness $(\beta=-.14, p<0.01)$, and Conscientiousness $(\beta=-.17, \mathrm{p}<0.01)$. The negative direction of regression coefficient implies that in cases of more expressed personality traits, a lower value on the Depression scale is expected. 
Personality TRaits as PREDictors of DePREssion...

\begin{tabular}{|c|c|c|c|}
\hline & & STRESS & \\
\hline & $\beta$ & Statistical significance & \multirow{6}{*}{$\begin{array}{l}\text { Model summary } \\
\mathrm{R}=.61 \\
\mathrm{R}^{2}=.37 \\
\text { Statistical significance }=.00\end{array}$} \\
\hline EXTRAVERSION & -0.03 & 0.23 & \\
\hline AGREEABLENESS & -0.08 & 0.00 & \\
\hline CONSCIENTIOUSNESS & -0.05 & 0.07 & \\
\hline NEUROTICISM & 0.57 & 0.00 & \\
\hline OPENNESS TO EXPERIENCE & 0.05 & 0.05 & \\
\hline
\end{tabular}

TABle 3: Regression ANALYSIS: MULTIPLE REgRESSION ANALYSIS (ENTER PROCEDURE): PERSONALity TRAITS AS STRESS PREDICTORS (TABELA 3. REgRESIONA ANALIZA: MULTIPLA REGRESIONA ANALIZA (ENTER POSTUPAK): OSOBINE LIČNOSTI KAO PREDIKTORI STRESA)

The regression model made by personality traits (Extraversion, Agreeableness, Conscientiousness, Neuroticism and Openness to experience) explains $37 \%$ of the criterion variable Stress. The largest individual contribution to Stress prediction is achieved by the personality trait Neuroticism $(\beta=.57, \mathrm{p}<0.01)$. In addition to that, the personality trait Agreeableness is related to Stress in a statistically significant way, however, this correlation is of a low intensity $(\beta=-.08, p<0.01)$, as well as the personality trait Openness to experience $(\beta=.05, p<0.05)$.

\begin{tabular}{|c|c|c|c|}
\hline & & ANXIETY & \\
\hline & $\beta$ & Statistical significance & \multirow{6}{*}{$\begin{array}{l}\text { Model summary } \\
\mathrm{R}=.52 \\
\mathrm{R}^{2}=.27 \\
\text { Statistical significance }=.00\end{array}$} \\
\hline EXTRAVERSION & -0.07 & 0.12 & \\
\hline AGREEABLENESS & -0.06 & 0.03 & \\
\hline CONSCIENTIOUSNESS & -0.12 & 0.00 & \\
\hline NEUROTICISM & 0.45 & 0.00 & \\
\hline OPENNESS TO EXPERIENCE & 0.00 & 0.95 & \\
\hline
\end{tabular}

TABle 4: Regression ANALYSIS: MultiPle REGRESSION ANALYSIS (ENTER PROCEDURE): PERSONALITY TRAITS AS ANXIETY PREDICTORS (TABELA 4. REgRESIONA ANALIZA: MultiPla REgRESIONA ANALIZA (ENTER POSTUPAK): OSOBINE LIČNOSTI KAO PREDIKTORI ANKSIOZNOSTI)

The regression model made by personality traits (Extraversion, Agreeableness, Conscientiousness, Neuroticism, and Openness to experience) explains $27 \%$ of the criterion variable Anxiety. The 
largest individual contribution in the prediction of this variable is achieved by the personality trait Neuroticism $(\beta=.45, p<0.01)$, whereas a statistically significant correlation between the personality trait Agreeableness $(\beta=-.06, p<0.05)$ and Conscientiousness $(\beta=-.12, p<0.01)$ and Anxiety as a criterion variable exists.

\begin{tabular}{|c|l|r|r|r|r|r|}
\hline \multicolumn{2}{|c|}{} & \multicolumn{1}{c|}{ AS } & \multicolumn{1}{c|}{ SD } & \multicolumn{1}{c|}{ T } & \multicolumn{1}{c|}{ DF } & \multicolumn{1}{c|}{ SIG. } \\
\hline \multirow{2}{*}{ DEPRESSION } & male & 5.30 & 4.76 & 1.35 & 941 & .18 \\
\cline { 2 - 5 } & female & 4.89 & 4.25 & & & \\
\hline \multirow{2}{*}{ ANXIETY } & male & 4.24 & 3.95 & -2.96 & 954 & .00 \\
\cline { 2 - 5 } & female & 5.07 & 4.34 & & & .00 \\
\hline \multirow{2}{*}{ STRESS } & male & 7.72 & 4.54 & -5.01 & 938 & \\
\cline { 2 - 5 } & female & 9.26 & 4.53 & & & \\
\hline \hline
\end{tabular}

TABLE 5: GENDER DIFFERENCES IN EXPRESSING DEPRESSION, ANXIETY, AND STRESS ON THE EXAMINED SAMPLE (TABELA 5. POLNE RAZLIKE U IZRAŽENOSTI DEPRESIVNOSTI, ANKSIOZNOSTI I STRESA NA ISPITANOM UZORKU)

These results show that there is a difference between boys and girls in expressing Anxiety $(\mathrm{t}=-2.96, \mathrm{p}<0.01)$ and Stress $(\mathrm{t}=-5.01$, $\mathrm{p}<0.01)$. These states are more expressed with girls.

\begin{tabular}{||l|l|r|r|r|r|r|}
\hline \multirow{2}{*}{ DEPRESSION } & \multicolumn{1}{c|}{ AS } & \multicolumn{1}{c|}{ SD } & T & \multicolumn{1}{c|}{ DF } & \multicolumn{1}{c|}{ SIG. } \\
\hline \multirow{3}{*}{ Anxiety } & $3^{\text {rd }}$ grade & 5.05 & 4.58 & .09 & 942 & .93 \\
\cline { 2 - 5 } & $4^{\text {th }}$ grade & 5.03 & 4.43 & & & \\
\hline \multirow{2}{*}{ Stress } & $3^{\text {rd }}$ grade & 4.66 & 4.09 & -.79 & 956 & .43 \\
\cline { 2 - 4 } & $4^{\text {th }}$ grade & 4.87 & 4.36 & & & .36 \\
\hline \hline
\end{tabular}

TABLE 6: DIFFERENCES IN EXPRESSING DEPRESSION, ANXIETY, AND STRESS IN RELATION TO GRADE ON THE EXAMINED SAMPLE (TABELA 6. RAZLIKE U IZRAŽENOSTI DEPRESIVNOSTI, ANKSIOZNOSTI I STRESA U ODNOSU S OBZIROM NA RAZRED NA ISPITANOM UZORKU)

No differences were noted in expressing Depression, Anxiety and Stress between the third and the fourth grade students. 
Personality TRaits as PREDictors of DePREssion...

\begin{tabular}{|c|l|r|r|r|r|r||}
\hline \multirow{3}{*}{ StRESS } & & SUM OF SQUARES & DF & MEAN SQUARE & F & SIG. \\
\cline { 2 - 6 } & Between Groups & 667.31 & 9 & 74.14 & 3.60 & .000 \\
\cline { 2 - 6 } & Within Groups & 19205.46 & 932 & 20.61 & & \\
\hline \multirow{2}{*}{ ANXIETY } & Between Groups & 361.88 & 9 & 40.21 & 2.27 & .016 \\
\cline { 2 - 6 } & Within Groups & 16790.13 & 948 & 17.71 & & \\
\hline \multirow{2}{*}{ DEPRESSION } & Between Groups & 244.00 & 9 & 27.11 & 1.34 & .212 \\
\cline { 2 - 6 } & Within Groups & 18895.39 & 934 & 20.23 & & \\
\hline \hline
\end{tabular}

TABLE 7: DIFFERENCES IN EXPRESSING DEPRESSION, ANXIETY, AND STRESS REGARDING SCHOOL ON THE EXAMINED SAMPLE (ANOVA) (TABELA 7. RAZLIKE U IZRAŽENOSTI DEPRESIVNOSTI, ANKSIOZNOSTI I STRESA U ODNOSU S OBZIROM NA ŠKOLU NA ISPITANOM UZORKU)

Based on shown results, we can conclude that there are differences in expressing stress $(\mathrm{F}=3.60, \mathrm{p}<0.01)$ and anxiety $(\mathrm{F}=2.27, \mathrm{p}<0.05)$ with students attending different schools. For a more detailed analysis, an LSD test results follow.

\begin{tabular}{|c|c|c|c|c|}
\hline (I) $\mathrm{SCHOOL}$ & (J) SCHOOL & $\begin{array}{l}\text { MEAN DIFFERENCE } \\
(\mathrm{I}-\mathrm{J})\end{array}$ & $\begin{array}{l}\text { STD. } \\
\text { ERROR }\end{array}$ & SiG. \\
\hline \multicolumn{5}{|c|}{ DEPENDENT VARIABLE - STRESS } \\
\hline TRADE SCHOOL & “9. maj” Gymnasium school & 2.01 & .64 & .002 \\
\hline \multirow{6}{*}{$\begin{array}{l}\text { FOOD-CHEMISTRY } \\
\text { SCHOOL }\end{array}$} & $\begin{array}{l}\text { "Svetozar Marković" Gymnasi- } \\
\text { um school }\end{array}$ & -1.49 & .64 & .020 \\
\hline & $\begin{array}{l}\text { "Bora Stanković" Gymnasium } \\
\text { school }\end{array}$ & -1.36 & .65 & .036 \\
\hline & Economic school & -1.56 & .66 & .018 \\
\hline & Tourism school & -1.54 & .65 & .017 \\
\hline & Trade school & -2.41 & .65 & .000 \\
\hline & Medical school & -3.11 & .66 & .000 \\
\hline
\end{tabular}

TABLE 8: AN REVIEW OF AN LSD TEST FOR COMPARING DIFFERENCES AMONG GROUPS (TABELA 8. LSD TEST ZA POREĐENJE RAZLIKA IZMEĐU GRUPA) 


\begin{tabular}{|c|c|c|c|c|}
\hline \multirow{7}{*}{ MEDICAL SCHOOL } & $\begin{array}{l}\text { "Svetozar Marković" Gymnasi- } \\
\text { um school }\end{array}$ & 1.62 & .65 & .012 \\
\hline & $\begin{array}{l}\text { "Stevan Sremac" Gymnasium } \\
\text { school }\end{array}$ & 1.85 & .65 & .004 \\
\hline & $\begin{array}{l}\text { "Bora Stanković" Gymnasium } \\
\text { school }\end{array}$ & 1.75 & .65 & .007 \\
\hline & “9. maj” Gymnasium school & 2.71 & .66 & .000 \\
\hline & Economy school & 1.55 & .66 & .019 \\
\hline & Tourism school & 1.57 & .65 & .016 \\
\hline & Food-chemistry school & 3.11 & .66 & .000 \\
\hline \multicolumn{5}{|c|}{ DEPENDENT VARIABLE - ANXIETY } \\
\hline \multirow[t]{2}{*}{ TRADE SCHOOL } & $\begin{array}{l}\text { "Bora Stanković" Gymnasium } \\
\text { school }\end{array}$ & 1.23 & .59 & .037 \\
\hline & “9. maj” Gymnasium school & 1.42 & .59 & .016 \\
\hline \multirow{3}{*}{$\begin{array}{l}\text { FOOD-CHEMISTRY } \\
\text { SCHOOL }\end{array}$} & Trade school & -1.80 & .60 & .003 \\
\hline & Medical school & -2.06 & .61 & .001 \\
\hline & Music school & -1.62 & .75 & .032 \\
\hline \multirow{6}{*}{ MEDICAL SCHOOL } & $\begin{array}{l}\text { "Svetozar Marković" Gymnasi- } \\
\text { um school }\end{array}$ & 1.29 & .59 & .028 \\
\hline & $\begin{array}{l}\text { "Stevan Sremac" Gymnasium } \\
\text { school }\end{array}$ & 1.30 & .59 & .029 \\
\hline & $\begin{array}{l}\text { "Bora Stanković" Gymnasium } \\
\text { school }\end{array}$ & 1.50 & .60 & .013 \\
\hline & “9. maj” Gymnasium school & 1.69 & .60 & .005 \\
\hline & Tourism school & 1.22 & .59 & .041 \\
\hline & Food-chemistry school & 2.06 & .61 & .001 \\
\hline
\end{tabular}

TABLE 8: AN REVIEW OF AN LSD TEST FOR COMPARING DIFFERENCES AMONG GROUPS (TABELA 8. LSD TEST ZA POREĐENJE RAZLIKA IZMEĐU GRUPA)

The results of the LSD post hoc test show that with the students coming from Trade school stress is more expressed than with students coming from "9. maj" Gymnasium school. In addition to that, anxiety with these students is more expressed than with their peers coming from "Bora Stanković" Gymnasium school and "9. maj" Gymnasium school, as well as Food-chemistry school. With the Medical school students, stress and anxiety are more expressed in com- 
parison to the students coming from other schools. Contrary to that, these states are statistically less expressed with the students coming from Food-chemistry school in comparison to other schools.

\section{DISCUSSION OF THE RESULTS}

The main aim of this research paper was to test the predictive power of personality traits in predicting affective states - depression, anxiety, and stress with secondary school students of higher grades. Having in mind a very turbulent adolescent period, as well as challenges before the young people in this period, it was expected that these states would be expressed more intensively than usually. However, the average student achievements imply that stressful experiences are the most expressed, whereas anxiety and depression are less expressed. Among the personality traits, the most expressed one is Openness to experience, which was expected bearing in mind the population of the examined sample.

Earlier theoretical considerations have almost consistently proven that personality traits which predispose people to negative emotional reactions - Extraversion and Neuroticism, as defined by the five-factor model of personality (Costa and McCrae, 1980; David et. al., 1997; Lucas and Fujita, 2000; Meyer and Shack, 1989; Watson and Clark, 1992, according to Marić, 2010). Extraversion is related to the tendency to experience pleasant affective states in a highly positive manner, whereas Neuroticism is related to negative affectivity. Other personality traits of the five-factor model - Openness to experience, Agreeableness, and Conscientiousness are most usually related to positive affectivity; whereas they are in a negative correlation with experiencing negative emotions (McCrae and Costa, 1991; Watson and Clark, 1992).

The results of this research showed that based on Neuroticism, all the three examined emotional states - Depression, Anxiety, and Stress could be predicted. Such a result is expected bearing in mind that Neuroticism is theoretically labeled as a dimension referring to negative emotionality. Depression could also be predicted based on Extraversion and Agreeableness values; however, the correlation between these two dimension is in the opposite direction to the afore mentioned one, implying that, in cases of high values of these personality traits, the expected value on the Depression scale will be lower. Extrovert people are characterized by sociability, 
enterprise, activity, meaning that such people generally resort to positive emotions. Agreeableness, as a personality trait, is a characteristic of people which are kind, cooperative, and ready to help others. Adolescents that express these personality traits are unlikely to tend to depressive reactions. On the contrary, when facing problems, they are expected to turn to others and to activities in the world around them.

The largest individual contribution to Stress prediction, as mentioned, was achieved by the personality trait Neuroticism, whereas the personality trait Agreeableness is correlated to Stress in a statistically significant way as well, the correlation, however, being of a low intensity.

Lines of personality that showed correlation to both high and low psychological distresses on different populations are Extraversion, Neuroticism, and Conscientiousness. People who express Neuroticism as a line of personality are more likely to experience distress, since they respond to everyday stressors in a negative way and report to experience a larger number of stressful experiences (Duggan, Sham, Lee, Minne and Murray, 1995, according to Vrućinić, 2014).

In addition to Neuroticism, the personality traits Agreeableness and Conscientiousness contribute to Anxiety prediction. As mentioned earlier, researchers mostly find that Agreeableness, Conscientiousness, and Openness correlate to emotional states to a lower degree in comparison to Extraversion and Neuroticism (McCrae and Costa, 1991). In cases in which correlations were noted, Agreeableness was most often positively correlated to positive affective responses, and negatively with negative emotional reactions (McCrae and Costa, 1991; Watson and Clark, 1992).

The results obtained on this sample also speak in the favor of the fact that Agreeableness and Conscientiousness are correlated to Anxiety in a negative manner. People who express these traits lean toward positive affectivity; their nature is mild; they are sensitive, altruistic, i.e. reliable and responsible, with strong self-control. If these traits are expressed to a great extent, they could lead to violating psychic stability and emotional balance. On the other hand, if these traits are expressed to a moderate level, they will not lead to negative emotional response.

The results show that there is a difference between boys and girls in expressing Anxiety and Stress. These emotional states are more expressed with girls. Previous researches have almost consistently 
shown that women express negative emotions, such as sadness and fear more often (Brody and Hall, 2008, according to Jovanović et. al., 2014) as well as that they face a higher level of risk for developing depressive and anxiety disorders (Leach, Christensen, Mackinnon, Windsor and Butterworth, 2008, according to Jovanović \& al., 2014), this result thus being in accordance with the expected.

In addition to that, the results show no differences in expressing Depression, Anxiety, and Stress with the third and the fourth year students of secondary schools, as the studied sample suggests. These differences were somewhat expected having in mind that the fourth year students face the task of choosing their further professional development. The suspense carried by each decision could, according to the expectations, contribute to a higher level of stress and anxiety; however, this result did not prove itself as a statistically significant one, meaning that there are other factors as well which cause the occurrence of negative emotional states.

Bearing in mind that the students from the sample come from 10 different schools in Niš, it was examined whether there were differences in expressing stress, anxiety, and depression with the students coming from different schools. The results have shown that such differences do exist in terms of expressing stress and anxiety, as well as that, in comparison to the other schools, generally these states are more expressed with the students of Medical school, whereas the students of Food-chemistry school do not express stress and anxiety to a significantly lower extent. In order to explain these differences, variables concerning the general climate in schools, the width of the curriculum, as well as the relationships between students and their teachers should be examined.

CONCLUSION The period of adolescence, as one of the most turbulent periods in life, carries a feeling of internal fear, concern, restlessness, and worry. The most expressed fears torturing a young individual are fears and concerns related to school, personal competences, and physical health. At the crossroads of their lives, such as attending college, getting a job, and similar situations representing a challenge in adapting, the occurrence of a number of anxiety symptoms is expected. Types of fears, as well as their quality depend on the age, leading the process of maturing towards strengthening the internalized problems. The increase in cognitive abilities enables adolescents to think about themselves in the future (Wenar, 2003). 
Furthermore, facing the problems of growing up could be stressful for particular individuals, whereas inadequate ways of facing stressful experiences could lead towards pulling in or depressive reactions.

This research confirmed the assumptions about the role of personality traits in expressing negative affectivity, enabling us, however, to explain depression, anxiety, and stress only partially. Therefore, other power correlates should be included, emphasizing those factors that usually influence the young in the period of adolescence, which the examinees of this sample pertain to. The sample of secondary school students in their final years was chosen in order to identify those levels of depression, anxiety, and stress which would be more expressed, bearing in mind the numerous tasks students are expected to face. However, all three emotional states are expressed on a level below the average which might lead to the conclusion that adolescents use age-appropriate strategies of overcoming stress, as well as that they have not taken the roles of adults yet, seeing these changes as challenges, rather than threats.

\section{REFERENCES}

Diener, E., Wirtz, D., Tov, W., Kim-Prieto, C., Choi, D. W., Oishi, S. \& Biswas-Diener, R. (2010). New well-being measures: Short scales to assess flourishing and positive and negative feelings. Social Indicators Research, 97, 143-156.

Goldberg, L. R. (1990). An alternative "description of personality": The Big Five factor structure. Journal of Personality and Social Psychology, 59, 1216-1229.

Hudek-Knežević, J., Krapić, N. \& Kalebić-Maglica, B. (2009). Organizacijski stres i stavovi prema radu kao prediktori zdravstvenih ishoda: prospektivno istraživanje. Društvena istraživanja, 18(1-2), 129-149.

Lovibond, S. H. \& Lovibond, P. F. (1995). Manual for the Depression Anxiety Stress Scales. Sydney: Psychology Foundation.

John, O. P., Donahue, E. M. \& Kentle, R. L. (1991). The Big Five inventory - versions $4 a$ and 54. Berkley, CA: University of California, Berkley, Institute of Personality and Social Research.

John, O. P. \& Srivastava, S. (1999). The big five trait taxonomy: History, measurement, and theoretical perspectives. In: L. A. Pervin \& O. P. John (Eds.), Handbook of personality: Theory and research (102-138). New York: The Guilford Press.

Jovanović, V., Gavrilov-Jerković, V., Žuljević, D. \& Brdarić, D. (2014). Psihometrijska evaluacija Skale depresivnosti, anksioznosti i stresa-21 (DASS-21) na uzorku studenata u Srbiji. Psihologija, 47(1), 93-112. 
Krapić, N. (2005). Dimenzije ličnosti petofaktorskog modela i radno ponašanje. Psihologijske teme, 14 (1), 39-55.

Marić, M. (2010). Osobine ličnosti, životni događaji i anksioznost adolescenata.Primenjena psihologija, 1, 39-57.

McCrae, R. R. \& Costa, P. T. (1991). Adding liebe und arbeit: The full five-factor model and well-being. Personality and Social Psychology Bulletin, 17, 227-232.

Međedović, J. (2009). Bazična struktura ličnosti i kriminalitet. Primenjena psihologija, 2 (3), 339-367.

Mroczek, K. D. \& Kolarz, C. M. (1998). The effect of age on positive and negative affect: A developmental perspective on happiness. Journal of Personality and Social Psychology, 75, 1333-1349.

Nolen-Hoeksema, S. (2000). The Role of Rumination in Depressive Disorders and Mixed Anxiety/Depressive Symptoms. Journal of Abnormal Psychology, 109 (3), 504-511.

Otašević, B. \& Kodžopeljić, J. (2016). Osobine ličnosti modela velikih pet i sociodemografske varijable kao prediktori važnih životnih ciljeva. Primenjena psiholgija, 9 (1), 23-40.

Rutter, M. (1981). Stress, coping, and development: Some issues and questions. Journal of Child Psychology, Psychiatry and Allied Disciplines, 22, 323-356.

Smederevac, S. \& Mitrović, D. (2006). Ličnost - metodi i modeli. Beograd: Centar za primenjenu psihologiju.

Spielberger, C. D. (1972). Conceptual and methodological issues in anxiety research. In: C. D. Spielberger (Ed.), Anxiety: Current trends in theory and research (481-492). New York: Academic Press.

Vrućinić, Ž. (2014). Povezanost karakteristika ličnosti sa ispoljavanjem stresa i načinom njegovog prevladavanja. Evropski defendologija centar za naučna, politička, ekonomska, bezbjednosna, sociološka i kriminološka istraživanja, Banja Luka.

Watson, D. \& Clark, L.A. (1992). On traits and temperament: General and specific factors of emotional experience and their relation to five-factor model. Journal of Personality, 60, 441-476.

Wenar, C. (2003). Razvojna psihopatologija i psihijatrija: od dojenačke dobi do adolescencije. Jastrebarsko: Naklada Slap.

Zotović, M. (2002). Stres i posledice stresa: prikaz transakcionističkog teorijskog modela. Psihologija, 35 (1-2), 3-23. 
МИЛЕНА М. ВУЈИЧИЋ

УНИВЕРЗИТЕТ У НИШУ, ФИЛОЗОФСКИ ФАКУЛТЕТ

ПСИХОЛОШКО САВЕТОВАЛИШТЕ ЗА СТУДЕНТЕ

ДУШАН Ј. РАНЪЕЛОВИЋ

УНИВЕРЗИТЕТ У ПРИШТИНИ СА ПРИВРЕМЕНИМ СЕДИШТЕМ

У КОСОВСКОЈ МИТРОВИЦИ, ФИЛОЗОФСКИ ФАКУЛТЕТ

КАТЕДРА ЗА ПСИХОЛОГИЈУ

РЕЗИМЕ

КАРАКТЕРИСТИКЕ ЛИЧНОСТИ КАО ПРЕДИКТОРИ ДЕПРЕСИВНОСТИ, АНКСИОЗНОСТИ И СТРЕСА КОД УЧЕНИКА

ЗАВРШНИХ РАЗРЕДА СРЕДЬИХ ШКОЛА

Адолесценција као животни период одликује се многим могућностима за раст и развој, али је то и период у коме се сукоठљавају екстреми у расположењу, осећањима, енергији, идеологији, период пун конфликата и немира. Многи млади људи се налазе на прекретници, често су несигурни по питању одабира факултета, несигурни у погледу сопствених капацитета и потенцијала и недовољно упознати са тржиштем рада и принципима његовог функционисања, одлучују се да наставе родитељска занимања или бирају занимања у складу са избором својих пријатеља. Период адолесценције као један од најбурнијих периода у току животног циклуса са собом носи осећај унутрашњег страха, зебње, тензија и забринутости. Најизраженији страхови који муче једну младу особу јесу страхови и бриге везани за школу, личне компетенције и физичко здравље. Већина поменутих чинилаца може допринети већој анксиозности, мањој толеранцији на стрес и депресивности младе особе која није спремна за низ промена које се од ње очекују. На то да ли ће се и на који начин манифестовати ова стања утичу бројни фактори, али оно што се очекује јесте да и особине личности младе особе имају неког удела у њиховом испољавању.

Полазећи од модела структуре личности Великих пет, основни циљ спроведеног истраживања је био испитивање предиктивне моћи особина личности у испољавању депресивности, анксиозности и стреса код ученика завршних година средњих школа. Испитивање је спроведено на узорку од 977 ученика треће и четврте године из десет средњих школа у Нишу. Полна структура узорка била је 369 младића и 607 девојака. У истражи-

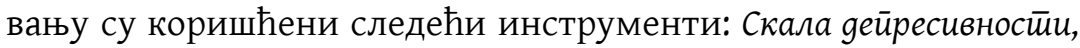
анксиозностии и сйреса (DASS-21; Lovibond and Lovibond, 1995) и Ин- 
венйар Великих ӣeӣ (Big five Inventory - BFI: John, Donahue and Kentle, 1991). Резултати су показали да регресиони модел који чине особине личности (екстраверзија, пријатност, савесност, неуротицизам и отвореност ка искуству) објашњава $26 \%$ критеријумске варијабле анксиозност. Највећи појединачни допринос у предикцији ове варијабле има особина личности неуротицизам $(\beta=.34, p<0.01)$. Остале особине личности које статистички значајно доприносе предикцији критеријумске варијабле су екстраверзија $(\beta=-.17, p<0.01)$, пријатност $(\beta=-.14, p<0.01)$ и савесност $(\beta=-.17, p<0.01)$. Исти модел објашњава 37\% критеријумске варијабле стрес. Највећи појединачни допринос у предикцији стреса има особина личности неуротицизам $(\beta=.57, p<0.01)$. Осим тога особина личности пријатност статистички значајно је повезана са стресом, али је корелација ниског интензитета $(\beta=-.08, p<0.01)$, као и особина личности отвореност ка искуству $(\beta=.05, p<0.05)$. Овај модел објашњава 27\% критеријумске варијабле анксиозност. Највећи појединачни допринос у предикцији ове варијабле има особина личности неуротицизам $(\beta=.45, p<0.01)$, док постоји статистички значајна повезаност и између особина личности пријатност $(\beta=-.06, p<0.05)$ и савесност $(\beta=-.12, p<0.01)$. Резултати показују да постоји разлика између младића и девојака у изражености анксиозности $(\mathrm{t}=-2.96, \mathrm{p}<0.01)$ и стреса $(\mathrm{t}=-5.01$, $\mathrm{p}<0.01)$. Код девојака су ова емоционална стања израженија. Нема разлика у изражености депресивности, анксиозности и стреса између ученика трећег и четвртог разреда средње школе на испитаном узорку.

Овим истраживањем су потврђене претпоставке о улози особина личности у испољавању негативног афективитета, али се на основу њих само делимично могу објаснити депресивност, анксиозност и стрес. Стога би требало укључити и друге потенцијалне корелате, са нагласком на факторе који уобичајено делују у периоду адолесценције коме припадају и испитаници овог узрока.

КљУчНЕ РЕчи: особине личности, депресивност, анксиозност, стрес, средњошколци.

Овај чланак је објављен и дистрибуира се под лиценцом Creative Commons Ауторство-Некомерцијално Међународна 4.0 (СС BY-NC 4.0 |

https://creativecommons.org/licenses/by-nc/4.0/).

This paper is published and distributed under the terms and conditions of the Creative Commons Attribution-NonCommercial International 4.0 licence (CC BY-NC 4.0 | https://creativecommons.org/licenses/by-nc/4.0/). 